\title{
Dignidad y Via Crucis del Poder Judicial
}

\author{
por el Dr. Héctor CORNEJO CHAVEZ \\ Catedrático de Derecho Civil en la Facultad de Derecho de la \\ Universidad Católica.
}

Por la índole de su función, por el ideal humano que lo inspira y por el instrumento que utiliza para realizarlo, el Poder Judicial inviste relievante significación en la estructura constitucional de una democracia. Está llamado, en efecto, a restablecer el equilibrio roto por la violación de un derecho o de uno de los principios en que reposa la organización colectiva. Está llamado a imponer la serena Majestad de la Justicia en el turbulento clima de pasiones en que la intransigencia suele situar el conflicto de intereses. Está llamado a proteger el derecho vulnerado no importa la humildad de quien lo tenga, y a sancionar el abuso no importa cuán poderoso sea quien lo cometa. Está llamado, en suma, a garantizar la paz social por la justicia $y$ con Ia ley.

Tún levontada misión conlleva, como es obvio, grave responsabilidad y arduas dificultades. Porque la Justicia que, in absiracto, se nos representa en la figura de una deidad infalible, ciega en su imparcialidad, inflexible en la sanción y matemática en la calificación de la culpa y la pena, está confiada, en la vida práctica, a hombres irremediablemente fallibles, La diosa de la balanza, la espada y los ojos vendados, que con helénica serenidad administraba justicia desde lo alto del Olimpo, se ha lastimosamente civilizado en estos tíempos benditos; y trocando la blanca túnica por la americana y otros adminículos igualmente prosaicos, suele ocultarse tras Ia figura de un buen padre de familia, ora gordo, ora enjuto, a menudo enfermo del hígado, casi siempre desmoralizado por injustas postergaciones $\mathrm{y}$ míseramente remunerado, que se pasa los días $\longrightarrow$ las tardes, por lo menos- tomando juramentos en nombre de Dios y fallando pleitos en nombre de la Nación, desde detrás de un escritorio arqueológico que comparte democráticamente con varios atareados escribientes, y desde el cual preside, sin toga, espada ni peluca, la olla de grillos vulgarmente conocida con el nombre de Juzgado.

Empero desde su pupitre hace lo mismo que la diosa: discernir justicia. Y si no usa venda, espada ni balanza, no es sólo por pudor estético o porque, dada la estrechez de nuestros "Palacios de Justicia", no tendría donde guardarios a buen seguro al final de la jomada, sino porque se supone que en una inmaculada probidad, en un indesmayable espíritu de 
trabajo $\mathrm{y}$ en una sólida preparación profesional tiene la justicia garantía bastante de imparcialidad, oportunidad, firmeza y acierto.

Inmaculadamente probo ha de ser el juez, en efecto. No sólo su vida pública, sino también su vida privada debe hallarse siempre en aptitud de exhibirse en escaparate de vidrio ante la conciencia moral de la colectividad. $Y$ en sus fallos no debe reflejarse jamás el halago del amigo, el temor al enemigo, la conveniencia del acreedor o la influencia de otras tentaciones aun más oscuras.

Necesita, además, un indesmayable espíritu de trabajo. Porque la hacienda, el honor $y$ la libertad de muchos hombres no deben quedar a las resultas de una sobremesa demasiado larga o de una digestión excesivamente plócida.

$\mathrm{Y}$ exige, en fin, una vasta preparación profesional, desde que la Justicia se administra con el Derecho. $Y$ el Derecho no es sólo cuestión de sentido común y buen criterio; como lo prueba la circunstancia de que so necesitan siete años de Universidad para aprenderlo.... a medias.

Probidad, esfuerzo y capacidad son las únicas llaves con que se abre la puerio de honor del Poder Judicial. Las otras -porque las hay - sólo abren las puertas de servicio y las ventanas.

No es, por eso, concebible que la investidura judicial sea conferida a nadie por sólo la obra de la influencia política, la amistad o el parentesco. La magistratura es honra de la que es preciso hacerse digno, y no pitanza o granjería. Es templo de sabiduría y no asilo de fracasados. No es trampolín, sino meta. Se entra en ella por la angosta senda de la honestidad y la competencia; y se asciende dentro de ella por la ardua escala de los méritos probados. No es, en una palabra, ni precio de servicios incondicionales, ni trofeo de sordas batallas libradas en pasillos y antesalas con el arma del regalo y la tarjeta. Es dignidad que se recibe con la frente alta, $y$ no mendrugo que se implora con la mano tendida.

Hemos tenido, tenemos aún por fortuna, magistrados integerrimos, Guardamos con veneración el recuerdo de los primeros, y admiramos diariamente la esforzada labor de los segundos. Sin embargo, el acierto de su designación no se ha debido al sistema vigente de nombramientos y promociones judiciales. Se ha debido, acaso, a factores imponderables que a veces permitan hacer con pautas tuertas renglones derechos y que, vendando con la más hermosa generosidad los ojos de un legítimo interés económico, permiten también que todavía existan profesionales brillantes que aspiren a ocupar los cargos comparativamente peor remunerados del Perú.

En tanto no se provea, pues, a una reforma del Poder Judicial, quienes, por razón profesional o por simple espíritu cívico, sentimos como nuestras Ias angustias de los que diariamente tienen que ver con la Justicia, sea administrándola, ora pidiéndola, hemos de confiar en que consideraciones como las expuestas pesen en el ánimo de quienes tienen en sus manos la próxima provisión de las vacantes existentes en la Corte Suprema de la República.

Lima, Octubre de 1957. 